\title{
TEACHING STYLE OF PROFESSION WORLD TEACHERS AND ITS CHOICE OF LEARNING PROJECT
}

\section{Anna ZUBATÁ - Jitka PLISCHKE}

\begin{abstract}
The article discusses the context of the teaching style of profession world teachers and choice of teaching methods, especially project method. Researching survey is detected a discrepancy between the positive opinions of teachers and students of teaching technical education and information on realization of project teaching and the low representation of project teaching here. There are some possible causes of this condition.
\end{abstract}

Key words: career decision-making, teaching style of teachers, learning style of student, project education.

\section{VYUČOVACÍ STYL UČITELE SVĚTA PRÁCE A JEHO VOLBA PROJEKTOVÉ VÝUKY}

Resumé: Stat' pojednává o souvislosti vyučovacího stylu učitele tematického okruhu Svět práce a volby vyučovacích metod, zejména projektové metody. Výzkumným šetřením je zjištěn nesoulad mezi pozitivními názory učitelů a studentů učitelství technické a informační výchovy na realizaci projektové výuky a nízkým zastoupení projektové výuky zde. Jsou formulovány možné přičiny tohoto stavu.

Klíčová slova: kariérové rozhodování, vyučovací styl učitele, učební styl žáka, projektová výuka.

\section{1 Úvod}

Kariérové rozhodování žáka na ZŠ je složitý proces, jehož výsledkem by měla být správná, optimální volba či rozhodnutí o žákově budoucím povolání, popř. kariéře. Rodina spolu se žákem v této složité situaci sehrává nejdůležitější roli, na tom se shodují odborné publikace jednoznačně, viz mj. (Hlad'o, 2009), přičemž úloha školy, školských i mimoškolských organizací není zpochybňována. Jejich role je informativní (o profesích, jejich rysech a o cestě k profesím - o studiu mj. na vyšších stupních škol) a vzdělávací ve smyslu př́pravy na kariérové rozhodování i realizaci rozhodnutí. Zejména učitelé podílející se na výuce Světa práce a Občanské výchovy by měli významně prrispět žákovi $\mathrm{k}$ optimálnímu rozhodnutí. Kariérové rozhodování a rozhodnutí musí respektovat danosti žáka a na druhé straně vyžaduje znalosti profesí, jejich nároky a cestu $\mathrm{k}$ nim a také znalosti pracovního trhu. Jen vyvážené rozhodnutí mezi těmito póly je úspěšné. Představy o obou uvedených pólech kariérového rozhodování vycházejí, pochopitelně kromě významného vlivu okolí, ze žákových zkušeností - o sobě (na jeho sebepoznání a sebehodnocení) a o profesích. Přri respektování zmíněné priority žáka a rodiny při kariérovém rozhodování je tak úlohou školy vytvářet a/nebo podporovat znalosti a zkušenosti „na obou pólech“ - o žákovi i o profesích. Realizace této úlohy se však na obou pólech výrazně liší podle žáků (někdo na lékaře, jiný na strojního inženýra), to omezuje možnosti frontální výuky. Významnou otázkou při výuce směřující ke kariérovému rozhodování žáka je tedy volba vyučovacích metod a postupů, za optimální považujeme projektovou metodu. $\mathrm{Na}$ souvislosti využívání projektové metody $\mathrm{v}$ této výuce je zaměřena tato stat'.

\section{Kariérové rozhodování a vhodné vyučovací metody}

Pomineme-li instituce působící mimo ZŠ, je úspěšné kariérové rozhodování žáka podporováno především prací výchovného poradce (plní i činnosti kariérového poradce) a významně učitelem a výukou tematického okruhu Svět práce, v Rámcových vzdělávacích programech pro základní vzdělávání (dále RVP ZV) je to ,jediný povinnýc tematický okruh vzdělávací oblasti Člověk a svět práce, vhodný do vyšších ročníků. $K$ cílovému zaměření vzdělávací oblasti Člověk a svět práce patří orientace „V různých oborech lidské činnosti, formách fyzické a duševní práce a osvojení potřebných poznatků a dovedností významných pro možnost uplatnění, pro volbu vlastního profesního 
zaměření a pro další životní a profesní orientaci“ (RVP, s. 82). Žák má rovněž prokázat $\mathrm{v}$ modelových situacích schopnost přiměřené sebeprezentace při vstupu na trh práce (RVP, s. 86).

Činnost výchovného poradce a učitelů směřuje takto k optimálnímu kariérovému rozhodnutí a připravenosti toto rozhodnutí realizovat. Analyzujme tuto situaci. Rozhodování je dle (Hartl, 2000) vědomá volba $\mathrm{z}$ možností, za situace nabízející „několik alternativ a vyžadující vzít v úvahu více faktorư". Rozhodování může směřovat $\mathrm{k}$ volbě cílů i prostředků. Ovlivněno je rozhodující se osobou (předsudky, emocemi, znalostmi a neznalostmi) a situací (vnějšími tlaky okolí, náladami, předpisy). Podle D. Fontany (s. 117118) lze při rozhodování vidět tento postup:

$\checkmark$ hledáme a rozlišujeme alternativy, které můžeme uplatnit, alternativ,

pokoušíme se předvídat výsledky

$\checkmark \quad$ vytváŕíme si přednostní pořadí alternativ,

$\checkmark$ odhadujeme pravděpodobnost, $\mathrm{s}$ jakou zvolená alternativa povede $\mathrm{k}$ úspěchu, přistoupíme $\mathrm{k}$ činu, nebo se záměru vzdáme (to při kariérovém rozhodování není dobře možné).

Při rozhodování je rozvažován jednak užitek, jednak pravděpodobnost a náklady jeho dosažení (Sternberg, s. 427). Promyšlené rozhodnutí potom dle (Sternberg, s. 428) zahrnuje - zvážení všech alternativ, využití maximálního množství informací, uvážení nákladů a rizik, pečlivou a správnou kalkulaci. Nabídce teorie popisující rozhodování jsme se pečlivě věnovali také proto, že v následujícím textu nepůjde již jen o rozhodování žáka o profesi, ale také o rozhodování učitele o vyučovacích metodách ve výše popsané výuce. Zde jsme zjistili jistou nesrovnalost mezi názorem učitelů a jejich reálnou činností.

\section{Projektová výuka a vyučovací styl učitele}

Nastolme otázku, jaké vyučovací metody by měly převažovat $\mathrm{v}$ tematickém okruhu Svět práce? Podle našeho názoru, který je podložen analýzou cílových záměrů a podmínek výuky, výše nastíněných, by měly být významně zastoupeny, ne-li převažovat, metody charakteristické relativně samostatnou činností žáků a umožňující zjištování informací, aktivní a tvořivou činnost, vlastní rozhodování, prezentaci a obhajobu výsledků své práce a tak vlastně i sebe. Jako zvlášt' výhodná se jeví projektová metoda, pokud se podíváme na její pozitiva, můžeme spatřit souvislost s požadavky na pojednávanou výuku. Dle R. Dytrtové se jedná o tato pozitiva projektové metody: aktivizace, samostatnost, sebevzdělávání, aplikace poznatků, rozšíření poznatků, týmová spolupráce, uplatnění zodpovědnosti. (Dytrtová, s. 19) Veškerá tato pozitiva žák může uplatnit právě při kariérovém rozhodování a tímto směrem ho může projektová metoda rozvíjet.

Také $\mathrm{z}$ průzkumu, který jsme provedli $\mathrm{v}$ roce 2011 u budoucích učitelů tematického okruhu Svět práce, vyplývá, že v tomto tematickém celku je podle jejich názoru nejvhodnější projektová výuka (Zubatá, 2011, 7); i to do značné míry podporuje uvedené stanovisko o významu projektové metody. $\mathrm{Z}$ dalšího průzkumu, který jsme konali v roce 2012, vyšlo najevo, že převážná část dotazovaných (studenti technické a informační výchovy) tíhne k učebnímu stylu aktivistů (Sitná, 2009), což dle D. Sitné znamená, že ve svém vzdělávání preferují projektovou výuku, praktické činnosti atd. Dále z hlediska ,požadavku“ na učitele těchto budoucích učitelů vyhovovalo jim nejlépe, mají-li jejich učitelé VŠ liberální a facilitací vyučovací styl, jak jej popisuje (Fenstermacher, 2008).

Ovšem - v roce 2011 bylo provedeno dotazníkové šetření určené především pro učitele tematického okruhu Svět práce. $Z$ něj vyšlo najevo, že zmínění učitelé sice vysoce pozitivně hodnotí projektovou výuku, ale ve svých hodinách ji adekvátně nepoužívají. Přednost dávají konzervativním metodám (Zubatá, 2011). Zde je uvedená nesrovnalost.

Domníváme se, že tito učitelé, minulí studenti, neměli výše popsané názory na učební a vyučovací styly odlišné od současných, což se ostatně v dotazníkovém šetření potvrdilo (vysoce hodnotili význam projektové metody). Proč tedy projektovou výuku realizují minimálně, jaké jsou možné důvody, je logická otázka.

\section{Možné důvody nerealizace projektové výuky/metody}

Možné přičiny nízké volby projektové výuky/metody při realizaci výuky tematického okruhu Svět práce rozdělíme pragmaticky (a tedy poněkud nepřesně) na přičiny subjektivní a na príičiny objektivní:

\section{$>$ Subjektivní príčiny}


Může jít o rozpor mezi názorem a jednáním (Čáp, s. 343), kdy názor je uznáván jako správný, ale nerespektován v jednání, není tedy dostatečným podnětem pro adekvátní jednání individua. Pro ilustraci - výzkum odpovědnosti českých dětí (2,5 tisíce žáků ZŠ ve věku $11-14$ let), konaný brněnskými psychology (Dolinská, 2002), ukázal, že děti ,jsou vcelku informovány, že člověk je odpovědný za sebe, za jiné lidi, za stav př́rody, mají pro to pojmovou zásobu“, v proklamativní rovině je vše ,jak má být". Avšak počet těch, kteří proklamace respektují, když se jedná o konkretizaci této odpovědnosti vzhledem $\mathrm{k}$ jejich osobě a činnosti, rapidně klesá.

Zde tedy může jít o neochotu učitelů podstoupit námahu spojenou s prováděním tohoto způsobu výuky, která pochopitelně může být zapříčiněna nejrůznějšími okolnostmi (únava, stres), které však mohou mít i vnější, objektivní příčiny. Je tedy možné (omlouváme se za „netaktní“ uvedení možnosti), že náklady spojené s prováděním projektové výuky by byly př́liš vysoké, viz výše uvedená teorie rozhodování.

\section{$>$ Objektivní príčiny}

Může jít o rozsáhlý komplex př́icin spojený s nedostatečnou připraveností učitelů na výuku tohoto tematického okruhu, na nedostatek pomůcek, metodického zajištění, ocenění dobré práce, neochotu ke spolupráci u sociálních partnerů, nedostatečné vědomí zacílení či smyslu výuky, nejistotu príi provádění některých obtížnějších činností (diagnostika předpokladů pro profese dostupnými prostředky atp.), chápání výuky jako málo významné. S tím může souviset i jistá prretíženost, školní klima i způsob zpracování ŠVP.

Není třeba zvlášt’ rozebírat, že zde je prostor pro dosti zásadní šetření, lze předpokládat možnost jak kvalitativního, tak kvantitativního výzkumu, prováděného taktně a s úctou $\mathrm{k}$ profesi učitele.

\section{Závěr}

Budoucí učitelé technické a informační výchovy tíhnou $\mathrm{k}$ projektové výuce. $\mathrm{V}$ následné praxi se tato užitečná tendence a názor podle našich zjištění spíš vytrácí. Je třeba zjistit, zda jde o vnější či vnitřní prríčiny tohoto rozhodování učitelů a které to jsou. Pokud se podaří tuto nesrovnalost více či alespoň méně objasnit, může výuka tematického okruhu Svět práce výrazněji pomáhat žákům v tak obtížné životní situaci, jako je kariérové rozhodování. Mohlo by jít o zjištění obohacující pedagogické myšlení.

„Tento článek vznikl za finanční podpory UP Specifického výzkumu PdF_2012_022, VLIV VYUČOVACÍHO STYLU UČITELE NA VOLBU PROGRESIVNÍCH METOD SE ZŘETELEM NA PROJEKTOVOU VÝUKU V TEMATICKÉM OKRUHU SVĔT PRÁCE. “

\section{Literatura}

[1] HLAĎO, P. Vliv sociálního okolí na kariérové rozhodování žáků při přechodu do vyššího sekundárního vzdělávání. In Pedagogická orientace roč. 20, č. 3. Česká pedagogická společnost, 2010. ISSN 1211-4669.

[2] RVP ZV - rámcový vzdělávací program pro základni vzdélávání [online] Praha: výzkumný ústav pedagogický. [cit. 2011-05-21]. Dostupné z www: <http://www.vuppraha.cz/wpcontent/uploads/2009/12/rvpzv_2007-07.pdf>.

[3] HARTL, P.; HARTLOVÁ, H. Psychologický slovník. Praha: Portál, 2000. ISBN 80-7178-303-X.

[4] FONTANA, D. Psychologie ve školní praxi. Praha: Portál, 2003. ISBN 80-7178-626-8.

[5] STERNBERG, R. J. Kognitivní psychologie. Praha: Portál, 2002. ISBN 80-7178-376-5.

[6] DYTRTOVÁ, R. Metody a prezentace výsledků efektivního vzdělávání. 1. vyd. Praha: Reprografické studio PEF ČZU, 2007. ISBN 97880-213-1674-4.

[7] ZUBATÁ, A. Konstruktivistické př́stupy při rozvíjení schopnosti kariérového rozhodování. In Technológie vzdelávania vprípravě učitelov prírodovedných a technických predmetov: Medzinárodná vedecko-odborná konferencia : sbornik referátì [CD-ROM]. Prešov: KFMT FHPV a KPTD PF PU, 2011.

[8] SITNÁ, D. Metody aktivního vyučováni Spolupráce žáků ve skupinách. Praha: Portál, 2009. ISBN 978-80-7367-246-1.

[9] FENSTERMACHER, G. D.; SOLTIS, J. F. Vyučovaci styly učitelũ. Praha: Portál, 2008. ISBN 978-80-7367-471-7.

[10] ZUBATÁ, A. Zavedení a využívání projektu $\mathrm{v}$ tematickém okruhu Svět práce na ZŠ. In Aktuální problémy pedagogiky ve výzkumech studentů doktorských studijnich programu VIII:sborník referátů [CD - ROM]. Olomouc: Univerzita Palackého v Olomouci, 2011. 
[11] ČÁP, J.; MAREŠ, J. Psychologie pro učitele. 1. vyd. Praha: Portál, 2001. ISBN 807178-463-X.

[12] DOLINSKÁ, J.; DOLINSKIJ, Odpovědnost člověka očima českých dètí. XX. mezinárodní kolokvium o řízení osvojovacího procesu (I. část) Vyškov: Vysoká vojenská škola pozemního vojska, 2002, s. 85 - 87. ISBN 80-7231-090-9.

Lektoroval: Mgr. Salvetová Leona
Anna Zubatá, Mgr.

Katedra technické a informační výchovy, Pedagogická fakulta UP, Žižkovo nám. 5, 77140 Olomouc, ČR, tel. 00420585635803 , e-mail: azubata@seznam.cz Jitka Plischke, PhDr. Ph.D., Ústav pedagogiky a sociálních studií, Pedagogická fakulta UP, Žižkovo nám. 5, 77140 Olomouc, ČR, tel. 00420585635173 ,

e-mail jitka.plischke@upol.cz 